\title{
Disempowering Traditional Spatial Arrangement of Dayak Community: A Case Study of Tumbang Marikoi Village, Central Kalimantan, Indonesia
}

\author{
Tari Budayanti Usop ${ }^{1, *}$, , Sudaryono ${ }^{2}$, and M. Sani Roychansyah ${ }^{2}$
}

AFILIATIONS
1. Doctoral Students of
Department of Architecture
and Planning, Gadjah Mada
University, Yogyakarta,
Indonesia
2. Department of Architecture
and Planning, Gadjah Mada
University, Yogyakarta,
Indonesia
* Correspondence:
taribudayanti77@mail.ugm.
ac.id

RECEIVED 2021-04-04 ACCEPTED 2022-01-08

COPYRIGHT @ 2022 by Forest and Society. This work is licensed under a Creative Commons Attribution 4.0 International License

\section{ABSTRACT}

The rapid industrialization in the last decades significantly changed the traditional spatial arrangement in Central Kalimantan Island. The indigenous community's traditional forest lands management and ownership were transferred to oil palm plantations and mining corporations. Therefore, it disempowered the traditional spatial arrangement by changing the community's living conditions and transforming their livelihood sources from primary (forests) to secondary and tertiary. The disempowered traditional spatial arrangement of the Tumbang Marikoi village community includes a living area with rivers, forests, and dwellings. They access the forest through the village Kahayan Hulu and the Marikoi River. There is no power grid in Marikoi Village, making them depend on a solar-powered energy generation facility for their daily activities, including gardening, gathering forest products, hunting, mining gold, and fishing. This study applied the phenomenological method to explain the traditional spatial disempowerment in Marikoi Village, Central Kalimantan, following corporate plantation powers and mining activities. The results indicated that the palm plantations affected the Dayak community's living space and daily life. Furthermore, the ownership and management of their customary land, enhancing their economic, social, cultural, and religious life, was transferred to large plantations. As a result, the community's traditional spatial arrangement was disempowered through river silting from soil drilling, cloudy river water, flooding, distant land for income (selling honey, vegetables, rattan, herbal medicine, and other forest wealth), farming restrictions by clearing land and losing sacred areas and ancestral rituals.

\section{KEYWORDS}

Disempowering; Traditional spatial arrangement; Living space; Forest; Rivers; Village; Tumbang Marikoi; Phenomenology

\section{INTRODUCTION}

Indonesia is a pluralistic nation with diverse ethnicities, cultures, and customs. The archipelago community managed and protected their ancestral territories through unique governance before implementing the Indonesian unitary state. Pluralism involves strategic development, improved welfare, and regional regulation through a just, prosperous and civilized governance structure. Traditional Spatial includes the indigenous community's territories and resources living in forests and rivers.

\subsection{Traditional spatial arrangements and planning}

Traditional spatial includes the indigenous community traditions, customs, and culture passed down between generations. The community uniquely uses traditional spaces and potential resources based on the universe's spiritual and religious instructions and messages. For example, they view the forest as stores providing various needs, clean air for the lungs, medicinal plants as their hospital, and food from plants. Furthermore, the indigenous community protects the forests, which contains the 
traditional customary tools that would be extinct with deforestation. In contrast, the modern spatial approach views the forests as economic resources for the potential commodity in the country's forest industry instead of the traditional management considered to improve the indigenous communities' welfare. However, traditional management is more sustainable.

The Indonesian Government Law 26,(2007) article one defined Spatial Planning as space consisting of land, sea, air, and earth, where humans and other creatures live, conduct activities and sustain spatial planning through structure and pattern. The spatial structure includes settlements based on the network facilities and infrastructure. In contrast, spatial pattern utilizes space for protection, industry, and cultivation. Spatial planning as a process control system is complex and systemized for humans, habitats, ecosystems, and the harmoniously intertwined environment. Ineffective spatial planning causes community disaster and acts as a savior, shield, and patron to prevent losses and accommodate social, cultural, and economic needs.

Traditional spatial arrangement naturally consists of the indigenous community users with traditional tools and customary law norms. It is a bottom-up and occurs through natural elements such as land as the motherland, the forest with its contents such as food, and the river as a network of lucky veins for the source of life. In contrast, modern spatial planning is a noble concept though inefficiently implemented, leading to government manipulation and top-up planning for economic benefits through development planning laws and regulations.

The community traditional spatial arrangement in Tumbang Marikoi village depends on the forest, currently threatened by development land competition. The community refers to the forest as "Himba", which, according to Law 41 (1999), is the state's green space that can be converted from a Production Forest into a plantation through a forest use permit. The indigenous community owns and sustainably maintains the forests as a source of livelihood. The village's community utilizes the areas' resources, including soil fertility, forest products, and rivers for fishing. The Forests are governed by religious values and sacred and profane spaces functions.

\subsection{Dayaks and their communities}

The Dayaks community were nomads moving from one area to another and transforming into sedentary inhabitation patterns (Egenter, 2006 in Usop, et al., 2021). The 1894 Peace of Meeting in Central Kalimantan gathered the Dayaks for peace resolution and prohibited the nomadic lifestyle, building a settlement culture (Usop, 1996 in Usop T. B., 2020). The permanent settlement transformation led to the indigenous community's territory development using the land resources.

The Indonesian Republic 1945 Constitution defines the indigenous community as a group of individuals living in a geographical area with similar identity, culture, land relations, territories, natural resources, as well as customs and value systems that determine political, social, and legal economic customary institutions, regulating the citizens. The traditional community in Central Kalimantan villages builds housing clusters in the forest along riverbanks and uses the rivers for trade transportation and communication between villages. The Dayak's traditional spatial homogeneity is a commonality shaping their life pattern and culture attached to the area (Sangalang, 2013) as their home close to the rivers and forests.

The communities in Central Kalimantan village live close to the river that facilitate various activities, such as clean water, transportation between villages, farming, fishing, and collecting forest products. The river provides a profane and sacred space as 
the Kaharingan (ancient religions) believed it is essential to life. Furthermore, the Tumbang Marikoi community has been attached to Kahayan Hulu River since birth and believes that those who do not know the river experience bad fortune ( $p a(i)$. For example, they perform an annual ritual (Nahunan) to accord names on 1-2 months boys, for thanksgiving of the mother and child healthy condition and repay those who helped the birth process. They take the (Nahunan) baby's name to the river to introduce nature and its environment, followed by prayers as an offering (sesajen) to the river.

\subsection{Tumbang Marikoi village as the case of phenomenology}

Google Map shows that Tumbang Marikoi village was small and remote in the 1980 s in the wilderness located in the Kahayan Hulu and Marikoi watersheds. It was formed after Gunung Mas Regency area (2002) was expanded in 2010 in the North Kahayan Hulu District. The village is located on a hilly road, 7 hours from the Palangka Raya capital. The Damang Batu District Forest area decreases annually, reducing biodiversity by changing productive forests to private oil palm plantations. Other causes are the mining companies' explorations through permits despite regulations restricting extensive tree cutting, and clearing and burning forests to expand traditional or community plantations for cultivation.

This study explained the disempowered traditional arrangement in Tumbang Marikoi Village affecting farming and cultural tradition. The disempowerment is due to forest burning restrictions following the state Law Regulation of the environment minister (2010) and the oil palm plantations development. The village community owned rubber plantations before its price reduction, causing them to sell to the oil plantation investors. As a result, the community lost their land, and the forest turned into oil palm plantations (2013). The land clearing restrictions affected their livelihoods and turned to illegal gold mining (PETI), which polluted Kahayan Hulu River, causing cloudy water, harmful consumption, itching, diarrhea, and vomiting blood. Therefore, the land-use changes and clearing restrictions affected spatial arrangement.

The spatial effects indicate developments that prioritize the economic aspects disregarding sustainability, ecology, and social aspects. The community spatial tradition is a unique settlement and a living space uniting the natural environment. Industrialization has caused socio-economic changes affecting the community's livelihood system and the environment. Therefore, this study focused on the Dayak community's traditional spatial arrangement disempowerment in Tumbang Marikoi village as a spatial phenomenon affecting their life. It discussed the spatial arrangement causes, the effects of development on the indigenous community, and sustainable development.

\section{MATERIALS AND METHODS}

This study explained the traditional spatial disempowerment in Tumbang Marikoi Village using a phenomenology approach that shows real phenomena. Although the results are not structured, constructed, or systematically designed, they show an obvious and strong problem (Vagle, Clements, \& Coffee, 2017). Phenomenology is a dynamic analysis method based on the participants' subjectivity.

\subsection{Types and Research Approaches}

This qualitative study applied a transcendental phenomenological approach, showing the highest meaning value component. It focused on a social group to explain their activities that form a grounded space and share their life experiences. 
Phenomenology explores the deepest subjects' understanding of their experiences to explain problems.

The approach examined the socio challenges of traditional communities affected by palm plantations development to reveal Individuals' conscious experience based on their perceptions and interpretations. The expression and physical documentation of the preposition shows the traditional society's spatial value. The sensation is obtained from people's experiences through their integrated understanding of their thinking. The study listened, recorded, and understood the society's life perspective value and meaning. Furthermore, the reality and facts in the field were observed by feeling, experiencing, and blending with their lives.

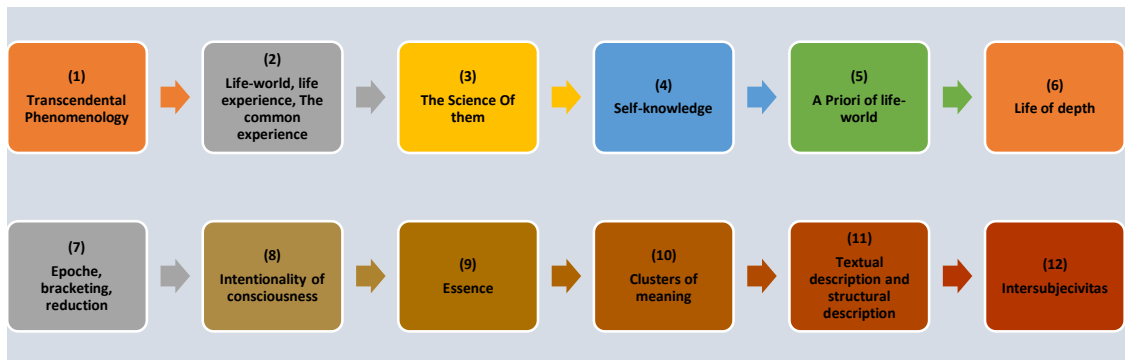

Figure 1. Terminology of Transcendental Phenomenology Concept. The teachings essence of phenomenological figures ranging from Husserl (1964), Ponti (1962), Schutz (1970) and Heidegger (2008) (Sudaryono, 2012)

Transcendental phenomenology shows that field surveys are conducted outside the ego to explore information from various sources. The ego is set aside to avoid preconceptions where there is no theory and hypothesis but a method of examining things. Other factors are life or shared experience and knowledge, where the essence of the phenomenological approach is information from them. They provide data as the subjectivity and objectivity in phenomenology. Deductive or quantitative analytical data were converted into descriptive qualitative narratives where a deep life is interpreted as a complete experience without a positive-negative intervention. This helps in understanding the phenomenon of the expressions used by the subject. Epoche is a delay or understanding of a study problem without rushing to conclude, while consensus awareness is the knowledge as a story theme from the study subjectivity. This study was determined as supreme meanings grouped as a pure conception. In textual and structural description or intentionality, humans appear as a transcendent, synthesizing subject and object, while intersubjectivity is when something is understood based on knowledge and experience (Sudaryono, 2012).

\subsection{Location}

This study was conducted in Tumbang Marikoi Village, Damang Batu District, Gunung Mas Regency, Central Kalimantan. It aimed to describe the disempowering due to land-use change into large oil palm plantations by observing the traditional spatial arrangement in the village. The forest is considered the heart of Borneo, a symbol of the living landscape of the Dayak community. There is a phrase of the Dayak community to remind the local government to "je tempun petak ela sampai manana ke sare" (the landowner ought not to plant on edge) to express their powerlessness (Usop, T. B., 2020). This phrase shows concern that large-scale investors dominate the local 
community's homeland amid industrialization.

The village has the Damang Batu sub-district and administrative center, a builtup area settlement of around 303 hectares with village area covering 5,381.4 hectares. In 2013, the village area was reduced by 5,000 hectares to 381.4 hectares for oil palm plantation. Damang Batu sub-district is divided into 1 RW and 7 RT, Urban Village Tumbang Marikoi. Also, it has seven villages, including Tumbang Posu, Tumbang Maraya, Lawang Kanji, Karetau Rambangun, Tumbang Anoi, Karetau Rambangun, Tumbang Anoi, Karetau Sarian, and Tumbang Mahuroi. The administrative boundaries of the village of Tumbang Marikoi are:

- North side : Tumbang Posu, Damang Batu District

- To the East : Tumbang Hamputung, Kahayan Hulu Utara District

- South side : Tumbang Tajungan, Kahayan Hulu Utara District

- West : Tumbang Tuwe, Rungan Hulu District

The topography is sloppy and hilly from south to the west, and hilly to mountainous in the middle to the west, east, and north.

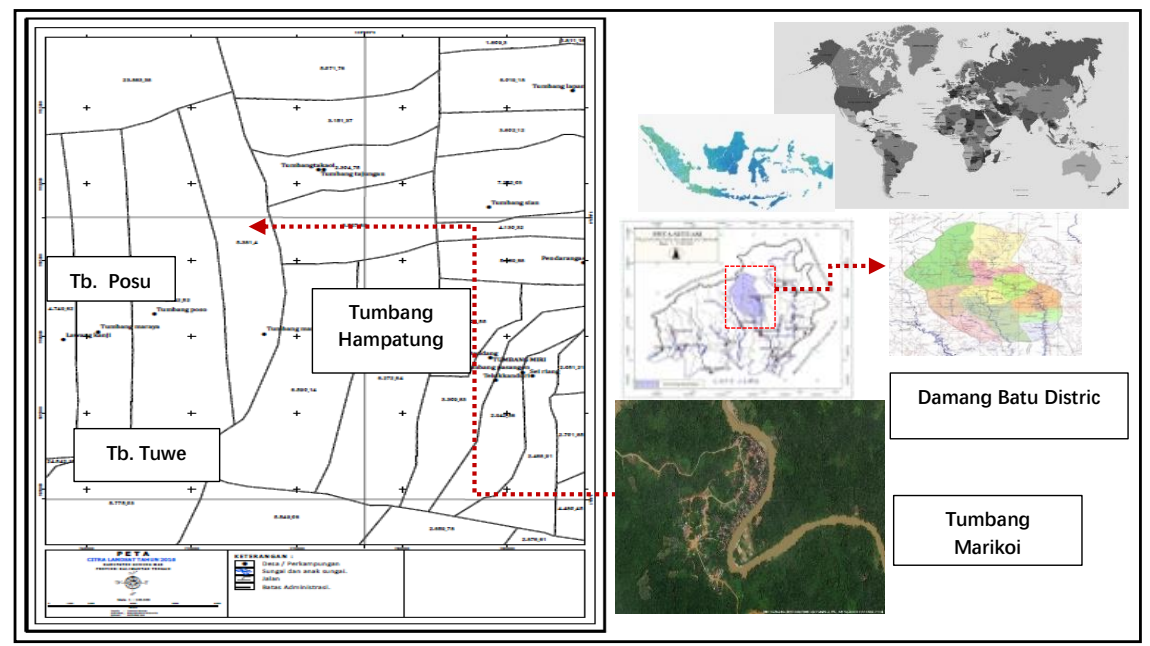

Figure 2. Study Locations Tumbang Marikoi Village, Damang Batu District (Kabupaten Gunung Mas, 2016)

\subsection{Data Collection}

Denzin and Lincoln (1986) and Amis (2011) stated that a phenomenology study answers questions about an event by focusing on two things. First, textural description refers to what is experienced by the study subject about a phenomenon, including the objective aspect, factual data, and things that occur empirically. Second, the structural description shows how the subject experiences and interprets their experience. This description contains opinions, judgments, feelings, expectations, and other subjective responses from various studies related to the experience.

The main data collection technique in a phenomenological study is in-depth interviews with subjects. The interviews must be recorded to deepen the data completeness using other techniques, such as participant observation and document tracing. 


\subsection{Data Analysis}

Data analysis uses work steps (Turinawe et al., 2015) by reducing, displaying, and verifying.

1. Reduction involved summarizing, selecting primary data, focusing on important things, looking for themes, and deleting unnecessary data.

2. Data was displayed using a Matrix to enable easy reading. The Stevick-Colaizzi-Keen analysis technique was employed using the following steps (Cresswell, 2012).

a. Describing the events experienced by the informant.

b. Assessing each verbal statement related to the study problem.

c. Recording relevant questions.

d. Creating lists or meaning units for specific themes.

3. The data were interpreted using text and discourse interpretation techniques by analyzing the informant's language, including message preparation, logical reasoning, and convincing facts. This includes the structure of ideas, thought processes, choice of speaker's language, and situations.

4. Verification or conclusions were drawn through a conditional disjunctive hypothesis proposition with two alternatives.

\section{RESULT}

\subsection{Map of the Tumbang Marikoi Village Area}

The area in Figure 3 is experiencing spatial attenuation and has been converted into two large oil palm plantation companies (PBS). The village area of 5,381.4 ha has been reduced to 381.4 ha. Therefore, the question is why the permit was given to convert the village area into a plantation. Another question is whether the community was involved in the permit issuance and its spatial implications for village life.

Figure 3 shows the area's appearance and satellite figure, indicating that Tumbang Marikoi village has large-scale oil palm plantations covering 5000 hectares of village land and is overpowered by two corporations. The shape and boundaries of the Village are shown in Figure 3A, while Figure 3B shows the yellow zone of Permanent Production Forest (HP) and the pink zone of Convertible Production Forest (HPK) controlled by PBS. Figure $3 \mathrm{C}$ shows the physical appearance of the oil palm plantation zone across the village zone in Damang Batu District.

The yellow zone is known as Production Forest (HP), designated to fulfill local community needs, development, and industry. The map shows forest planning in "Law 6 (2007) about forest regulation, management plans, and Forest Utilization." However, the question is why the plantations are large scale and wide, and whether the permits were granted to corporations following government rules. The plantations narrow the community management space towards the village area, ultimately disturbing the stability of the community life. Forests and customary law communities are two inseparable units. Disempowering against this traditional spatial arrangement cause losses when the forest land is cleared to grow crops and wood collected for building material. These activities have violated government regulations and resulted in sanctions for alleged forest destruction. However, the entry of corporations holding permits to release forest areas and cut down thousands of hectares was not sanctioned. Moreover, the wood cut down by large oil palm plantations was not given to village communities. This shows how the indigenous people existing on their customary land are disempowered. 


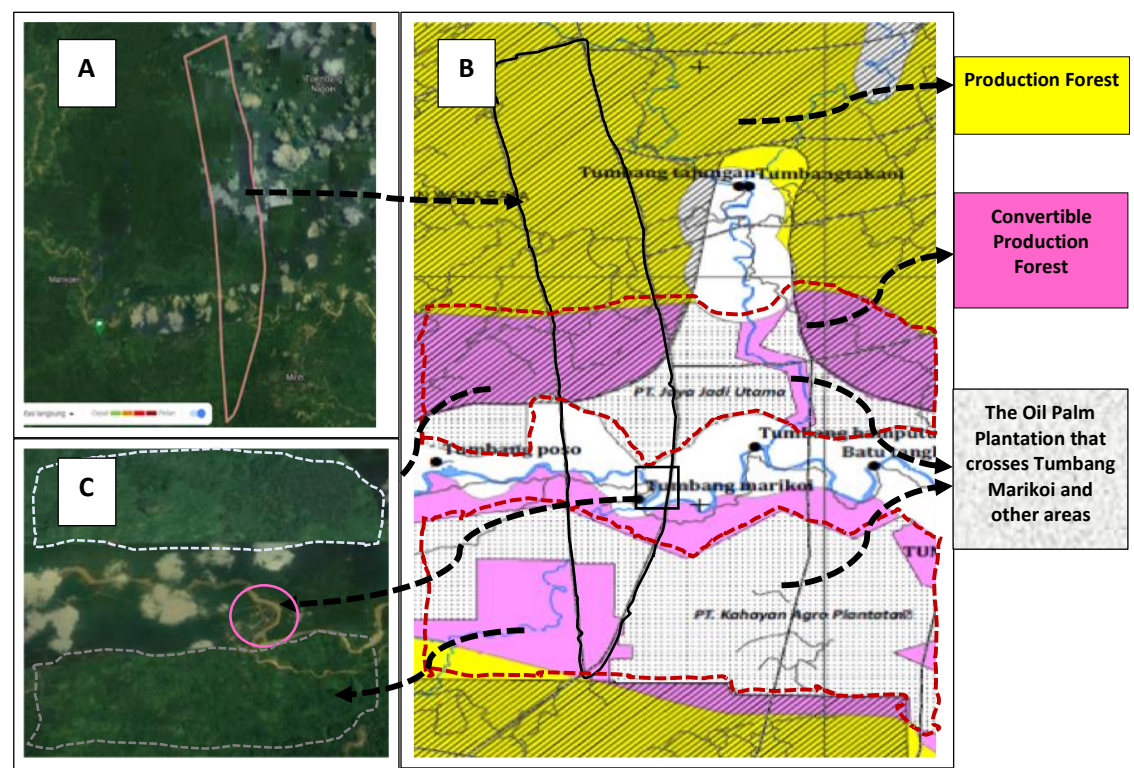

Figure 3. The Disempowering Spatial in Tumbang Marikoi Village: (A) Village Map Area Boundary; (B) Village Passed Area 2 Oil Palm Plantation Companies; (C) Village Overview Tumbang Marikoi, from Google Map satellite figure. The visible gray area is possibly obstructed (Kabupaten Gunung Mas, 2018)

The direct interviews found that farming is the main occupation in the Tumbang Marikoi village community, though other people work as illegal gold miners (PETI) (see figure 4).

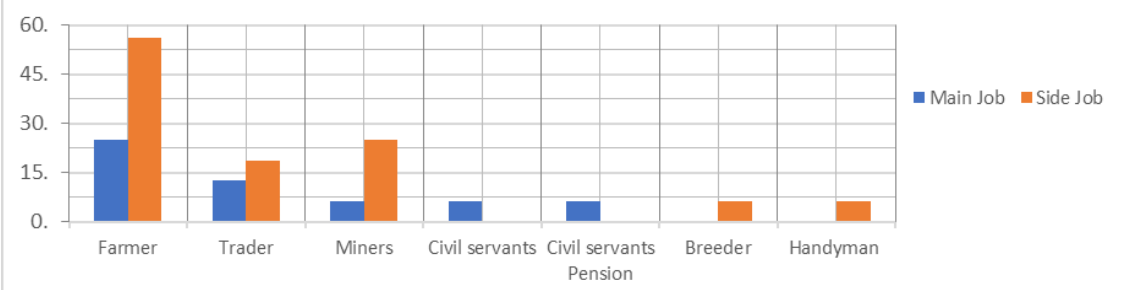

Figure 4. Types of Work for the Tumbang Marikoi Community

PETI increases the income of the village community, enabling them to buy a car and build or renovate their houses. Other people work as traders, but many are farmers and gatherers of forest products as their living space. Rural communities' lives are still guaranteed with food security, and the forest is still sustainable, but fish and meat are supplied from the city.

\subsection{Interpretation of the Meaning of the Emergence of Oil Palm Plantations}

In phenomenology, the informants' expressions are data on the findings of propositions based on Goerge Bealer's theory of truth (Bealer, 1999 in Hamzah, 2020). The substance of data selection, propositions have been classified based on facts found in the field. Table 1 shows the informants views obtained during the grand and mini tours to examine their experiences the disempowering conditions of the Traditional 
spatial arrangement in Tumbang Marikoi Village, as seen in Table 1.

Table 1. Informants Against Proposition Land Use Change in Tumbang Mariko Village

\begin{tabular}{|c|c|c|}
\hline No. & Informant's Name & Subjective Perspective \\
\hline 1. & $\begin{array}{l}\text { Dl } \\
\text { (Weaver, collecting } \\
\text { forest products) } \\
\text { Tumbang Marikoi }\end{array}$ & $\begin{array}{l}\text { "Now the location for farming is further away because the oil } \\
\text { palm plantation company has expanded its oil palm area, and } \\
\text { the plantation boundary agreement with the village is } 5 \text { (five) } \\
\mathrm{km} \text {, now it is only } 1 \text { (one) km away." }\end{array}$ \\
\hline 2. & $\begin{array}{l}\text { DN } \\
\text { (Farmers) talked } \\
\text { about the shifting } \\
\text { cultivation problem } \\
\text { Tumbang Marikoi }\end{array}$ & $\begin{array}{l}\text { "There was no attention from the government about the } \\
\text { solution for shifting cultivation. Finally, we turned to gold } \\
\text { miners, "aware" what we were doing was wrong and breaking } \\
\text { the law, but what could we do for the sake of life." Furthermore, } \\
\text { "it is different from companies that have obtained a permit, } \\
\text { which is not considered to be illegal. Even the terms clearing } \\
\text { land or clearing fields are considered to have the same } \\
\text { meaning, let alone clearing land for field purposes, we are still } \\
\text { considered to be breaking the law because we have burned the } \\
\text { land, it should be differentiated." }\end{array}$ \\
\hline 3. & $\begin{array}{l}\text { Ry } \\
\text { Tumbang Marikoi }\end{array}$ & $\begin{array}{l}\text { "With the existence of oil palm plantations, the village } \\
\text { community feels disadvantaged." }\end{array}$ \\
\hline 4. & $\begin{array}{l}\text { Ds } \\
\text { Tumbang Marikoi }\end{array}$ & $\begin{array}{l}\text { "My daily job is mining, I have a garden on the banks of Kahayan } \\
\text { Hulu River, but now there is no land to work on because there } \\
\text { is a lot of oil palm. We feel disturbed by the presence of oil } \\
\text { palm, the river becomes cloudy." }\end{array}$ \\
\hline 5. & $\begin{array}{l}\text { Dd } \\
\text { Tumbang Marikoi }\end{array}$ & $\begin{array}{l}\text { "Because there is oil palm, the land is difficult to find firewood, } \\
\text { absolutely not allowed for oil palm plantations." }\end{array}$ \\
\hline 6. & $\begin{array}{l}\text { UN } \\
\text { Tumbang Marikoi }\end{array}$ & $\begin{array}{l}\text { "The village community used to rely on the forest, but now } \\
\text { experiencing changes, the village community tends to rely on } \\
\text { PETI (gold mining without a permit), they know it is prohibited } \\
\text { by the government but still want it. Therefore, they live and } \\
\text { break the law." } \\
\text { "Besides that, it is also the disappointment of the community } \\
\text { members, although the human resources, specifically Gunung } \\
\text { Mas Regency, are available and abundant, in reality, the local } \\
\text { government does not help, specifically with natural products } \\
\text { (rubber/gums, rattan, etc.), there is no solution. People know } \\
\text { that PETI is destroying the ecosystem but due to economic } \\
\text { factors. }\end{array}$ \\
\hline 7. & $\begin{array}{l}\text { NBP } \\
\text { Tumbang Marikoi }\end{array}$ & $\begin{array}{l}\text { "If there is no support from the local government from } \\
\text { Community Forestry (HKM) and legalized with a traditional } \\
\text { spatial Certificate (SKTA), cultivating the land requires money, } \\
\text { but it is very helpful for indigenous people, the traditional } \\
\text { territory is considered valid if there is a certificate of traditional } \\
\text { spatial issued by the Damang Adat (customary humanity). The } \\
\text { reason for the community proposing the land they cultivate to } \\
\text { become traditional spatial is to avoid the authorities who } \\
\text { continue to think their activities are illegal and violate the law." } \\
\text { "PETI caused the cloudy river conditions; if that continued, then } \\
\text { the village could be abandoned due to the drilling of the PETI } \\
\text { gold mine, one village was abandoned due to damage, and } \\
\text { finally, the village was abandoned and turned into a place for } \\
\text { PETI, the incident was called "Lewu Bekarak." }\end{array}$ \\
\hline 8. & $\begin{array}{l}\text { HW } \\
\text { Palangka Raya }\end{array}$ & $\begin{array}{l}\text { "I follow the development of the farming community and feel } \\
\text { concerned about the disempowering traditional spatial of the }\end{array}$ \\
\hline
\end{tabular}

Usop et al. (2022) 


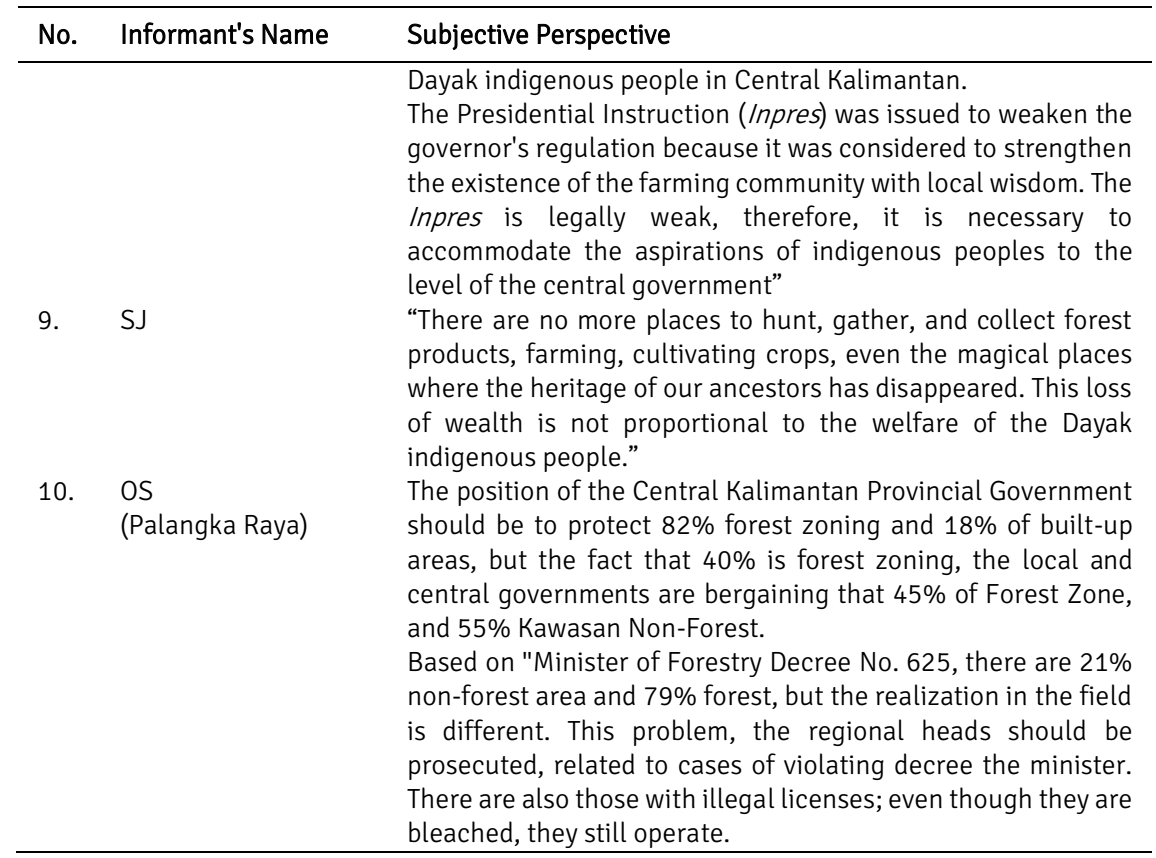

The propositions were synthesized based on the informant's experiences to find meaning and theme based on their expressions concerning what they feel about their village.

Table 2. Meaning and Themes of the Presence of Oil Palm Plantations

\begin{tabular}{|c|c|c|c|}
\hline $\begin{array}{l}\text { What is } \\
\text { experienced? }\end{array}$ & How is it experienced? & Findings Themes & $\begin{array}{l}\text { The Meaning of } \\
\text { the Presence of Oil } \\
\text { Palm Plantations }\end{array}$ \\
\hline $\begin{array}{l}\text { Forest is taken } \\
\text { up by oil palm } \\
\text { plantations }\end{array}$ & $\begin{array}{l}\text { - The search for farming } \\
\text { locations is getting } \\
\text { further } \\
\text { - The activity of collecting } \\
\text { forest products far away } \\
\text { - Feel wronged }\end{array}$ & $\begin{array}{l}\text { 1. Presence of Oil } \\
\text { Palm Plantation in } \\
\text { Tumbang Marikoi }\end{array}$ & \\
\hline $\begin{array}{l}\text { Farming is } \\
\text { becoming } \\
\text { increasingly } \\
\text { difficult }\end{array}$ & $\begin{array}{l}\text { - Difficult to find a farming } \\
\text { location } \\
\text { - Prohibition of clearing } \\
\text { land by burning } \\
\text { - Using the village area for } \\
\text { cultivation/farming }\end{array}$ & $\begin{array}{l}\text { Village } \\
\text { 2. The concept of } \\
\text { traditional spatial } \\
\text { arrangement in } \\
\text { the village of } \\
\text { Tumbang Marikoi }\end{array}$ & $\begin{array}{l}\text { The presence of } \\
\text { Oil Palm } \\
\text { Plantations in } \\
\text { Tumbang Marikoi } \\
\text { Village weakens } \\
\text { the Living Spaces }\end{array}$ \\
\hline & $\begin{array}{l}\text { - HKM is used as } \\
\text { traditional spatial for } \\
\text { farming activities, } \\
\text { utilizing forest products } \\
\text { (wood) }\end{array}$ & $\begin{array}{l}\text { 3. Forests and rivers } \\
\text { as living space } \\
\text { 4. Settlements in } \\
\text { Tumbang Marikoi } \\
\text { Village }\end{array}$ & $\begin{array}{l}\text { of Indigenous } \\
\text { Peoples. }\end{array}$ \\
\hline $\begin{array}{l}\text { Mining as a } \\
\text { source of } \\
\text { welfare }\end{array}$ & $\begin{array}{l}\text { - The price of gold has } \\
\text { gone up. }\end{array}$ & & \\
\hline
\end{tabular}




\begin{tabular}{|c|c|c|c|}
\hline $\begin{array}{l}\text { What is } \\
\text { experienced? }\end{array}$ & How is it experienced? & Findings Themes & $\begin{array}{l}\text { The Meaning of } \\
\text { the Presence of Oil } \\
\text { Palm Plantations }\end{array}$ \\
\hline & $\begin{array}{l}\text { - The proceeds from } \\
\text { mining are able to build } \\
\text { houses, buy cars, and pay } \\
\text { for college children. }\end{array}$ & & \\
\hline Kahayan Hulu & - The water is cloudy & & \\
\hline River water & $\begin{array}{l}\text { - There are fewer fish in } \\
\text { the river } \\
\text { - Community make drilled } \\
\text { wells } \\
\text { - Silting the river } \\
\text { - There was a flood in the } \\
\text { settlement }\end{array}$ & & \\
\hline $\begin{array}{l}\text { Difficult } \\
\text { economy }\end{array}$ & $\begin{array}{l}\text { - - Mining is an option } \\
\text { - Become an oil palm } \\
\text { worker if there are no } \\
\text { options }\end{array}$ & & \\
\hline $\begin{array}{l}\text { Tumbang } \\
\text { Marikoi Village } \\
\text { Floods }\end{array}$ & $\begin{array}{l}\text { - Move yourself to a high } \\
\text { place. } \\
\text { - It could happen "bekarak } \\
\text { lewu" (Village began to } \\
\text { be abandoned due to } \\
\text { environmental damage) }\end{array}$ & & \\
\hline
\end{tabular}

The presence of PBS for the Marikoi community separates people's living space from their daily routine, though the plantation creates jobs for the village community. Initially, they wanted to work in the palm oil company but later stopped because it was not their habit to work bound by time and rules, burdens, and responsibilities. Therefore, they think it is not easy to work 8 hours in the company rather than doing something else, such as gardening, hunting, collecting forest products, or PETI.

\subsection{Tumbang Marikoi Village}

The Village is located in the Kahayan Hulu watershed, whose tributary is Tumbang Marikoi. The width of the Marikoi River ranges between 40 and 80 meters. Geographically, Tumbang Marikoi is on a plateau and hilly, with linear settlement patterns along the river. The spatial structure is traditional with an attachment to the river, used for transportation, agricultural activities, and the community's economy. In the Tumbang Marikoi community, farming is the main activity, where cultivation system and spatial development are practiced on the mainland (see Figure 5). 


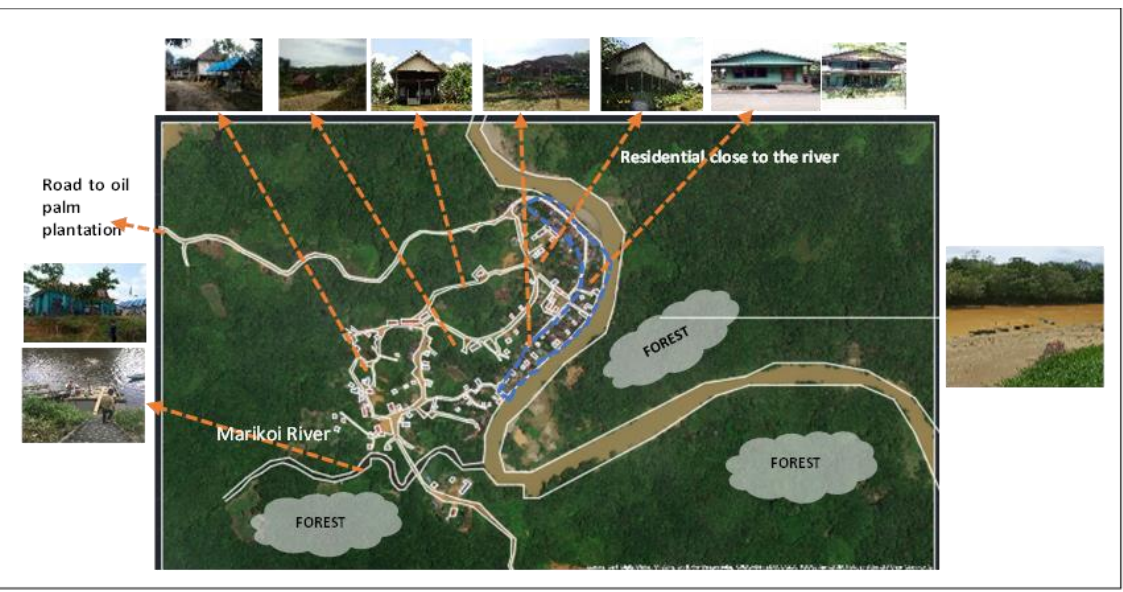

Figure 5. Shape of Tumbang Marikoi Village (Usop, 2020)

Based on the appearance on the map in Figure 5, this village consists of forming elements such as the environment formed by nature, humans, village communities, protected areas (forests), and networks (rivers). Therefore, a village between a forest and a river, in the form of a house on stilts, adaptive to the surrounding environment, indicates the concept of living in harmony with nature peacefully and intellectually. Furthermore, the blue dotted line in Figure 5 denotes is a settlement area close to the river, classified as low and prone to flooding. Some houses were displaced due to frequent flooding, and others moved to hilly areas.

This village recognizes the existence of the former (kaleka/lewu huran), which has become an orchard marked with durian trees. According to Riwut (2012), establishing the village is based on soil fertility, the number of forest products needed, and many of fish. In the future, when the soil fertility decreases or the required forest products get exhausted, people would leave to look for new, more promising areas. For this reason, many villages (lewu/dukuh) were empty because the residents had moved to other areas according to the agreement. Other signs of former villages are marked by the abundance of fruit trees, such as durian, rambutan, and mango. These signs are what the villagers call kaleka. Due to natural wealth, local people are spoiled by the surrounding resources, giving them enough to eat without working hard. Although the settlement development is stationary, Damang $\mathrm{Ngoa}^{\mathrm{Batu}}{ }^{1}$ stated that the villagers leave for other areas when the village is damaged or polluted. Consequently, an empty village means that the government has failed to carry out the development process, not because of a nomadic lifestyle.

This village has Huma Hai, or a great house, Bangkat Engget, but abandoned and uninhabited. Also, there is an old house made of bark, the stumbling blocks or houses storing bones, wooden, and concrete houses, as shown in Figure 6. This indicates the village is old and experiencing development and transformation.

\footnotetext{
${ }^{1}$ Personal communication (October 23, 2021)
} 

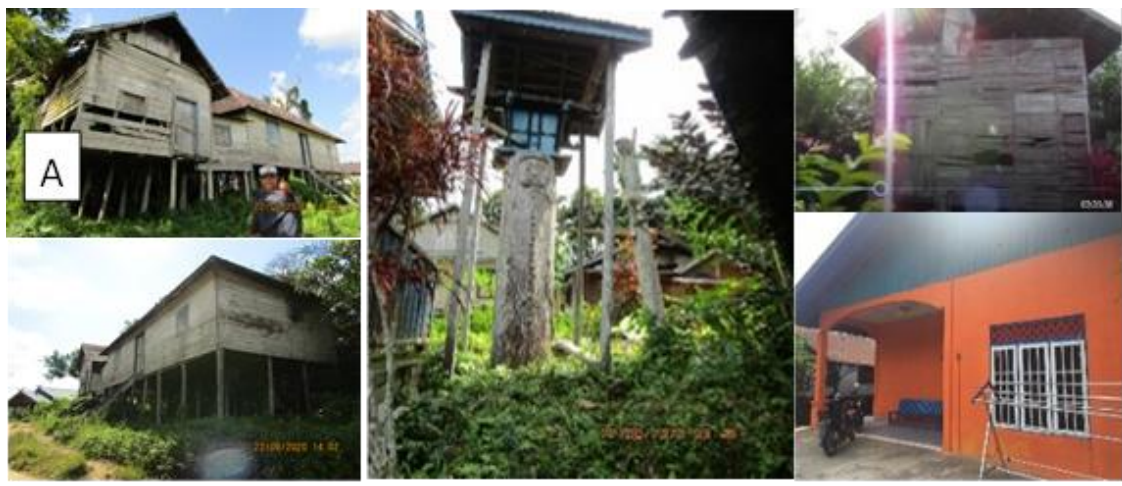

Figure 6. Built Environment and (left) A. Great House "Bangkat Engget's"

At the moment of Huma Hai Bangkat Engget's existence, Figure 6 left A shows one of the old uninhabited houses in this village. People lived in groups to build longhouses with big families in the past. However, during the Tumbang Anoi Peace agreement (History of the Integrity of the Dayak Tribes in Central Kalimantan, 1894 in Usop, KMA, 1996), changes occurred in Great House in a process called the Bekarak Betang incident or leaving Huma Hai (longhouse) for a single house. People could leave Huma Hai when considered capable and independent. Therefore, the process shown in Figure 7 indicates the journey to forming a village.

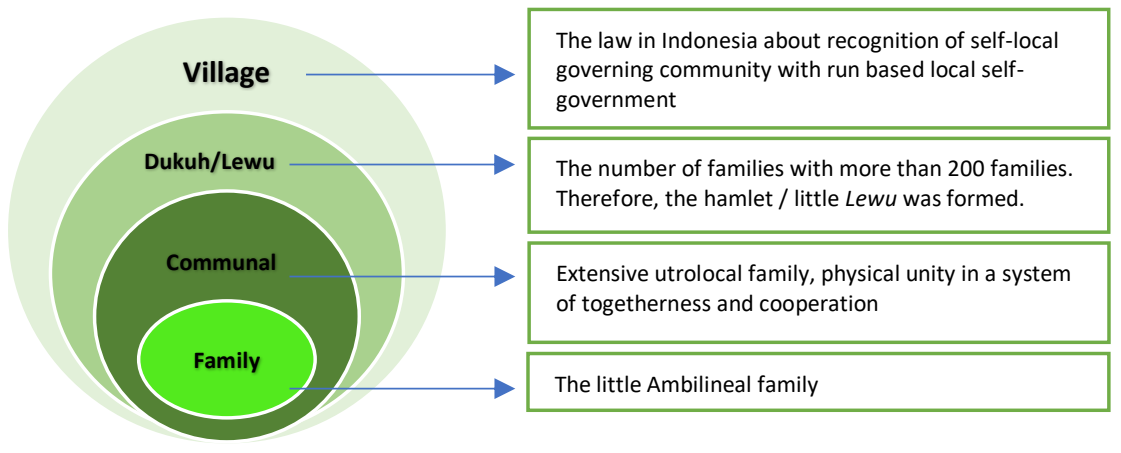

Figure 7. The Village Development Process (J. Danandjaja in Koentjaraningrat, 1999)

\section{THE POLLUTION OF THE KAHAYAN HULU RIVER AND TUMBANG MARIKOI RIVER}

Tumbang Marikoi Village is at Kahayan Hulu and Marikoi River. According to BPS Provinsi Kalimantan Tengah (2020), Kahayan River is the second largest river, stretching $600 \mathrm{~km}$. In the Dayak Ngaju language call of Kahayan River is batang danum maruang dohong (a long river that brings luck). The river is known as the lifeblood providing the demands of needs and economic life, though the upstream and downstream become problems.

The phrase a river is a paradise for all people and various necessities of daily life are found in Kahayan Hulu, one of which is fish. In the past, the fish were easily found in Kahayan and Marikoi Rivers, whose biodiversity has drastically reduced with the rise of PETI and oil palm plantations. PETI activities, such as draining and sucking river water, damage river ecosystems, and the environment. However, people are helpless 
because the income from rattan and rubber has not improved. Additionally, the demands and economic interests are problematic for the its community.

Table 3. Subjective Proposition Against Kahayan Hulu River and Marikoi River in Tumbang Marikoi

\begin{tabular}{|c|c|c|}
\hline No. & Informant's name & Subjective perspective \\
\hline \multirow[t]{6}{*}{1.} & $\begin{array}{l}\text { IG } \\
\text { Tumbang Marikoi }\end{array}$ & $\begin{array}{l}\text { In the past, looking for fish in the river was easy. They got } 1 \text { (one) } \\
\text { kilogram, a depth of } 1 \text { (one) meter down could be seen. However, } \\
\text { now the river's biological richness was decreased drastically with } \\
\text { the rise of PETI and oil palm plantations. }\end{array}$ \\
\hline & & $\begin{array}{l}\text { This beautiful story is only a memory. Now that Kahayan River has } \\
\text { changed, the river's biological wealth has decreased drastically, } \\
\text { along with the rampant encroachment of nature and the } \\
\text { environment in the ecosystem. }\end{array}$ \\
\hline & & $\begin{array}{l}\text { Now it is no longer easy to get fish for us villagers, and because } \\
\text { it has become a habit to eat fish which remains a daily necessity, } \\
\text { we get supplies from the city. }\end{array}$ \\
\hline & & $\begin{array}{l}\text { We believe that the river has a guardian, meaning that there are } \\
\text { spirits that are invisible at the bottom of the river, such as a } \\
\text { crocodile, one of the guardians of the unseen, people used to } \\
\text { meet crocodiles, and they believe that if you meet a crocodile, } \\
\text { was sign the river has much gold if you to dive, that is the secret. }\end{array}$ \\
\hline & & $\begin{array}{l}\text { In the past, I only dived to pick up rocks at the bottom of the river, } \\
\text { lifted them, then got gold, I used to be able to get } 3 \text { (three) grams } \\
\text { in } 1 \text { (one) day, and that used to be done when the dry season } \\
\text { came if it was the rainy season we could not work. }\end{array}$ \\
\hline & & $\begin{array}{l}\text { With the existence of Katok machines, gold miners have } \\
\text { penetrated Kahayan River channel starting in the } 2000 \mathrm{~s} \text {, not } \\
\text { knowing the seasons. They drain the river water from the river } \\
\text { banks until the river bodies become damaged. The gold miners } \\
\text { from the river's lower reaches, and the longer they move up to the } \\
\text { upper reaches. }\end{array}$ \\
\hline 2. & $\begin{array}{l}\text { UA } \\
\text { Tumbang Marikoi }\end{array}$ & $\begin{array}{l}\text { I am a traveling merchant, taking orders from the villagers of } \\
\text { Tumbang Marikoi, such as pomfret, tilapia, carp, catfish, and } \\
\text { pork. This fish supply is obtained from the Palangka Raya city to } \\
\text { sell the village of Tumbang Marikoi and its surroundings. It seems } \\
\text { that the current need for fish began in the } 1990 \text { s, and in } 1995 \text { for } \\
\text { the Dayak people, it has started to sell very well, especially since } \\
2003 \text { ago until now, it seems that the need for fish from that city } \\
\text { is increasing. Usually, when I go around the village, their orders } \\
\text { are from the end of the village to the end of the Kahayan Hulu } \\
\text { River, it can reach six pikulor } 100 \mathrm{Kg} \text { per } 2-3 \text { days. }\end{array}$ \\
\hline 3. & $\begin{array}{l}\text { NN } \\
\text { Tumbang Marikoi }\end{array}$ & $\begin{array}{l}\text { Today we work in line with the place, and tomorrow we will work } \\
\text { again. The work is the same, but the results can be nil, so getting } \\
\text { gold is uncertain. We believe that the river has magical people, } \\
\text { who sometimes get gold easily. We had to work around the clock } \\
\text { for up to } 10 \text { hours every day, targeting cliffs or river bodies, } \\
\text { excavating and spraying with katok machines and makeshift } \\
\text { equipment. Soil and rocks are channeled to a filter stage so that } \\
\text { material containing gold grains is separated from rocks and other } \\
\text { dirty soil, which is considered useless and thrown into the river. } \\
\text { To get gold continues to be repeated every day along the Kahayan }\end{array}$ \\
\hline
\end{tabular}




\begin{tabular}{ll}
\hline No. Informant's name & \multicolumn{1}{c}{ Subjective perspective } \\
\hline & $\begin{array}{l}\text { Hulu River, no more other considerations. Such as safety risks, } \\
\text { environmental impacts, and regulations and permits. } \\
\text { If there is a police raid, our belongings are confiscated, arrested, } \\
\text { and we know this work is without permission from the } \\
\text { government but what is the solution for us? At the Kahayan Hulu } \\
\text { Sector Police office, we asked for a solution, what jobs do well? } \\
\text { So that we can work legally and be recognized without any } \\
\text { hindrance from the authorities. }\end{array}$ \\
& $\begin{array}{l}\text { They are helpless because the production of rattan, rubber has } \\
\text { not improved. The demands of economic needs and interests } \\
\text { become a dilemma for the people of Tumbang Marikoi village. } \\
\text { Tumbang Marikoi } \\
\text { 5. The condition of the Kahayan Hulu River was polluted, we forbid } \\
\text { the villagers to consume the river water directly and not again } \\
\text { bathing on rivers and recommend having their bathroom at home, } \\
\text { including Marikoi River, which is very well preserved } \\
\text { Because Kahayan Hulu River is polluted, we prohibit the } \\
\text { community from exploiting the river in Marikoi. Let Marikoi River } \\
\text { be the source of clean water for Tumbang Marikoi. }\end{array}$ \\
\hline
\end{tabular}

The propositions in Table 3 were synthesized based on the informants' experiences to find meaning and theme based on their expressions concerning what they feel about their village.

Table 4. The Meaning and Theme of Kahayan Hulu and Marikoi River

\begin{tabular}{|c|c|c|c|}
\hline $\begin{array}{l}\text { What is } \\
\text { experienced? }\end{array}$ & How is it experienced? & Findings Themes & $\begin{array}{c}\text { The Meaning of } \\
\text { the Presence of } \\
\text { Oil Palm } \\
\text { Plantations }\end{array}$ \\
\hline $\begin{array}{l}\text { Kahayan } \\
\text { Hulu River }\end{array}$ & $\begin{array}{l}\text { - It used to be easy to } \\
\text { find fish } \\
\text { - The river water was very } \\
\text { clear and safe for direct } \\
\text { consumption in the } \\
\text { past. } \\
\text { - River biodiversity is } \\
\text { reduced } \\
\text { - The river is sacred, } \\
\text { there is a guardian } \\
\text { spirit }\end{array}$ & $\begin{array}{l}\text { 1. Decrease in river water } \\
\text { quality } \\
\text { 2. Mining gold activities } \\
\text { have damaged the } \\
\text { biological life of the } \\
\text { Kahayan Hulu River. } \\
\text { 3. Livelihood } \\
\text { transformation from } \\
\text { forest economy to }\end{array}$ & $\begin{array}{l}\text { River Damage } \\
\text { Occurs Due to }\end{array}$ \\
\hline $\begin{array}{l}\text { Marikoi } \\
\text { River }\end{array}$ & $\begin{array}{l}\text { - As a source of clean } \\
\text { water } \\
\text { - Rivers and forests on } \\
\text { Marikoi River are still } \\
\text { preserved. }\end{array}$ & $\begin{array}{l}\text { Illegal Gold Mining as } \\
\text { the fortune of sources } \\
\text { 4. River pollution } \\
\text { 5. The dependence on } \\
\text { food from the city }\end{array}$ & $\begin{array}{l}\text { Unlicensed Gold } \\
\text { Mining (PETI) }\end{array}$ \\
\hline $\begin{array}{l}\text { Illegal Gold } \\
\text { Miner }\end{array}$ & $\begin{array}{l}\text { - Mining is a source of } \\
\text { livelihood. } \\
\text { - Searching for gold with } \\
\text { the machine, the river is } \\
\text { getting worse } \\
\text { - Uncertain income }\end{array}$ & $\begin{array}{l}\text { 6. Marikoi River as a } \\
\text { source of clean water }\end{array}$ & \\
\hline
\end{tabular}




\begin{tabular}{|c|c|c|c|}
\hline $\begin{array}{l}\text { What is } \\
\text { experienced? }\end{array}$ & How is it experienced? & Findings Themes & $\begin{array}{c}\text { The Meaning of } \\
\text { the Presence of } \\
\text { Oil Palm } \\
\text { Plantations }\end{array}$ \\
\hline & - Keep on mining even if & & \\
\hline $\begin{array}{l}\text { Damage to } \\
\text { the Kahayan } \\
\text { Hulu River }\end{array}$ & $\begin{array}{l}\text { - River cliffs become } \\
\text { targets for mining gold } \\
\text { (PETI) }\end{array}$ & & \\
\hline & $\begin{array}{l}\text { - There is a lot of } \\
\text { sediment and garbage } \\
\text { due to river dredging }\end{array}$ & & \\
\hline & $\begin{array}{l}\text { - The river water is } \\
\text { cloudy }\end{array}$ & & \\
\hline $\begin{array}{l}\text { Food } \\
\text { dependence } \\
\text { on cities }\end{array}$ & $\begin{array}{l}\text { Now the supply of fish and } \\
\text { meat is obtained from the } \\
\text { city. }\end{array}$ & & \\
\hline
\end{tabular}

Subjective opinions from various villagers were based on the river receiving waste from PETI and PBS activities and the influence of this massive industry on the river water quality. The decline in its quality is marked by changes in watercolor and odor. The subjective proposition was strengthened by taking samples of 2 liters from the two rivers to assess the pollution level. Table 5 shows the results of testing ten parameters following the Quality Standards (Law 82, 2001).

Table 5. Results of River Water Sample Test in Tumbang Marikoi Village

\begin{tabular}{|l|r|r|r|r|r|r|r|r|r|r|}
\hline Sample & TDS & TSS & Fe & COD & $\begin{array}{c}\text { NH3- } \\
\text { N }\end{array}$ & $\begin{array}{c}\text { NO3- } \\
\text { N }\end{array}$ & $\begin{array}{c}\text { NO2- } \\
\text { N }\end{array}$ & pH * & CN & $\mathrm{SO}^{4}$ \\
\hline Kahayan Hulu & 19.3 & 113 & $\mathbf{0 . 2 0 2}$ & 11.3 & 0.07 & 0.83 & 0.008 & 6.6 & 0.002 & 3.31 \\
\hline Marikoi & 12.9 & $\mathbf{5 4 . 7}$ & $\mathbf{0 . 0 7}$ & 7.05 & 0.05 & 0.749 & 0.006 & 6.55 & 0.002 & 5.25 \\
\hline Threshold Value & $\mathbf{5 0 0}$ & $\mathbf{3 0}$ & $\mathbf{0 . 0 3}$ & $\mathbf{2 4}$ & $\mathbf{1 . 5}$ & $\mathbf{3}$ & $\mathbf{5 0}$ & $\mathbf{8 . 5}$ & $\mathbf{0 . 0 7}$ & $\mathbf{2 5 0}$ \\
\hline
\end{tabular}

(Source: Unit, Laboratory of Health and Calibration, 2021)

The results of the water content sample show that the water of the Kahayan Hulu River is more polluted than Marikoi River. The iron (Fe) content in both rivers looks high, and the TSS value exceeds the river water quality standard. Therefore:

- Industrial waste has three physical properties: turbid suspended matter increases and smells in these two rivers. Chemical properties are determined by chemical oxygen demand (COD), Total Suspended Solid (TSS), heavy metal iron (Fe), and high $\mathrm{pH}$. TSS reduces river water quality, resulting in disturbance, damage, and danger to all living things that depend on water sources.

- TSS causes cloudiness and reduces the light entering the water, reducing the benefits of it and causing the death of light-dependent organisms. The death of these organisms disrupts the aquatic ecosystem. When this amount of suspended matter settles, sludge formation could disrupt the flow in the channel, causing rapid silting.

- The iron (Fe) content in both rivers exceeds the acceptable quality standards, causing unpleasant colors, odors, tastes, and health problems such as nausea, damage to intestinal walls, and eye and skin irritation. During the interviews, the people of Marikoi Village (2018) stated that the river is no longer healthy because they feel itching on their bodies, vomiting blood, and diarrhea. Furthermore, the 
presence of PBS in this village adds to the large Fe content due to fertilizer waste from oil palm plantations.
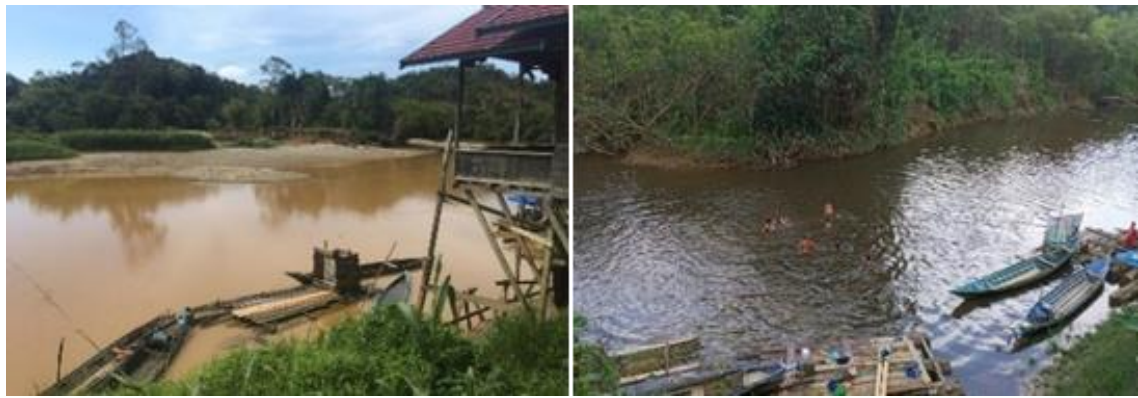

Figure 8. The River Condition in Tumbang Marikoi Village Kahayan Hulu River (Left)Marikoi River (Right).

\section{DISCUSSION}

The disempowering of traditional spatial arrangements in Tumbang Marikoi village has made the living space of indigenous peoples vulnerable because the village management area surrounded by forests with various functions is increasingly limited in its space for movement. As a result, a traditional spatial arrangement that functions as a living space is deprived of its rights. According to Law 529 (2012) regarding land acquisition for development in the public interest, the indigenous people are considered to have been released or had their rights revoked voluntarily for public interest concerning the traditional spatial arrangement. Law 41, 1999 concerning Forestry permits capital owners through a licensing scheme to exploit state forests. This is carried out without considering the rights and wisdom of indigenous peoples, as entrepreneurs take advantage of their customary forest. Therefore, this law rejects the enactment of the forestry law. In 2020, there was a new policy that the Government of Indonesia revoked Law 41 (1999) into the Job Creation Law expected to have an integrated licensing process because of many irregularities in previous permits.

Traditional forests defined in Law 41 (1999) are state forests located in the territory of traditional law communities. However, large oil palm plantations have disempowered traditional spaces, with various problems due to loss of livelihood sources. This has increased vulnerability because ecology is threatened by mass PETI activities and river pollution, with potential future generations. The issue of forests turning into plantations makes the government provide Community Forests (HKM) for use as customary or village forests and not controlled by oil palm plantations.

Forest land was turned into oil palm plantations due to a lack of understanding of traditional spatial arrangement regarding the rights and authority of customary land composed of forests, rivers, and living spaces. Furthermore, the government was interested in developing industrialization without considering the rights of indigenous peoples. Farming culture expands the community's customer right area or perwatasan where they open forests for farming, build ponds, open forests for spirits and ancestral spirits, and places to look for fish and rattan. This traditional activity is similar to opening a rubber plantation, abandoning it, and opening a new plantation. The old rubber groves are periodically harvested, although they are full of thickets. The community still recognizes such lands as their property or Watas lands (petak watas) and is preserved as their land regulated by customary law for the public interest. This 
recognition is important for the involvement and preservation of customary rights. Therefore, community farming activities are property passed on to their children and grandchildren, calling them land watas. The local community believes that failure to practice shifting cultivation makes people's gardens resemble rubber with no land expansion and no maintenance or customary rights of the village.

The area of this village is 5,381.4 ha, of which $95 \%$ or 5,000 hectares have been turned into large oil palm plantations, the remaining 303 hectares are living areas, while only 78.4 hectares are under forests. The forest is a space for survival, invaluable support for life, and has real ecological, socio-cultural, and economic benefits for life. Although forests are state property, they are not ownership, and the state has the authority to grant permits and rights to other parties based on community aspirations.

The people of Tumbang Marikoi cultivate garden vegetables in their yards, such as planting bananas, cassava leaf vegetables, and gardening long beans on their empty land. They initially used to farm far away but now practice farming only around the village, while rice is planted on new land in the HKM area as shifting fields. The community gets fish and meat from the city of Palangka Raya due to pollution and flooding problems in their village.

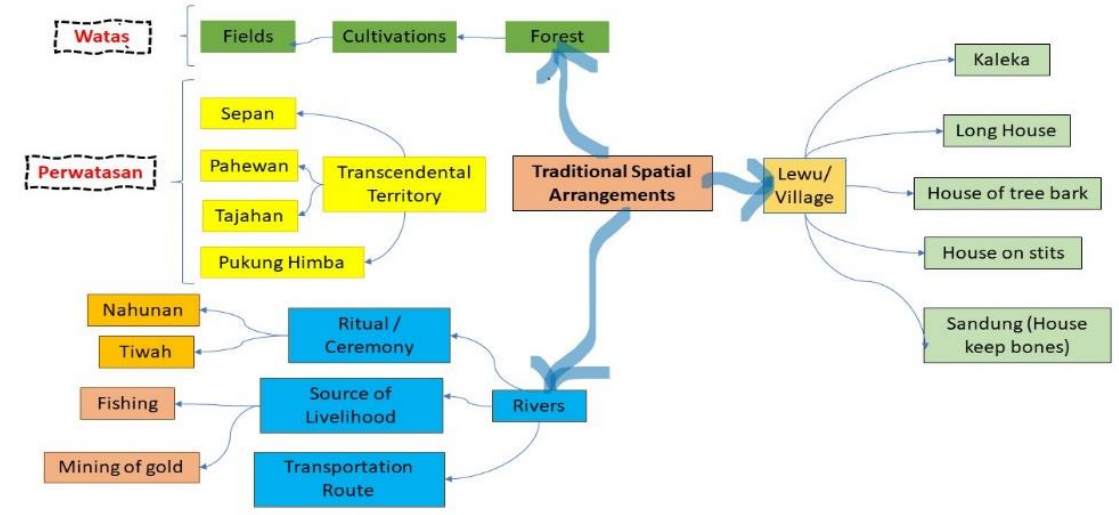

Figure 9. The Concept of The Dayak Traditional Spatial Arrangement (Usop, L. S. (2020), Mahar (2020), Harrison, et al. (2019)

In the traditional spatial arrangement, people initially lived close to the river as a transportation route and clean water and livelihood source. Although the forest is an area for farming and gardening, they manage the forest according to its function, such as the forest of Pahewan (sacred), Sepan Pahewan, a source of salt or mineral springs, Pukung Himba, Tajahan, the sacred forest where spirits reside, and Pukung Himba, used to move spirits. Indigenous peoples use it sparingly and maintain the sustainability of their Himba or jungle forests, as shown in Figure 9.

After entering a new era in 1991, the originally lewu traditional spatial arrangement turned into a village or Desa (a term for the government). The community space became increasingly narrow because the existing forest area in Figure 10 was taken over by large oil palm plantations (PBS). People that used to garden far away and moved around now practice farming only in their village area. Another transcendental phenomenon is converting forest areas into a large oil palm plantation (PBS) where oil palm workers died suddenly while working. The plantation party asked the village leader to perform traditional ritual ceremonies. In traditional spatial arrangements, 
forest areas consist of sacred areas to symbolize traditional life.

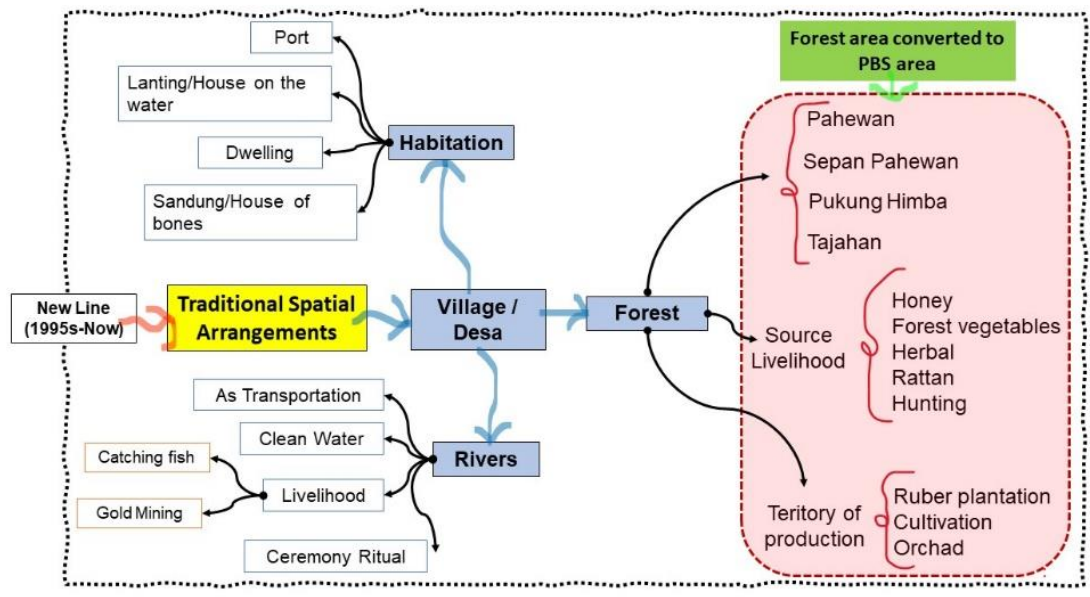

Figure 10. Transformation of Dayak Traditional Spatial Arrangement (Usop, T. B. (2020), Mahar (2020), Harrison et al., (2019)

The presence of large oil palm plantations causes harm to rural communities as objects of spatial disempowering. There is a decrease in environmental physicschemistry, biology quality, and health, social, economic, and cultural problems. While conducting interviews about what they experienced and felt based on their anxiety, attitudes, and perceptions about disempowering, the informants stated that it caused social conflict and health problems. Disempowering traditional spatial arrangement requires the protection of the rights of indigenous peoples in their living spaces. This would ensure their survival and sustainable development due to motivation that prioritizes the economic point without considering the environmental and social dimensions. The following conclusions were drawn based on the results of filed data and information collected in the field:

- Large oil palm plantations (PBS) bring huge losses to the village community.

- The area of utilization of the village community is decreasing, such as farming activities, fruit gardening, and collecting limited forest products.

- Declining quality and quantity of river water or decreasing water flow due to river water pollution, turbidity, and river sedimentation.

- There were social problems and unclear village boundaries with PBS. Villagers stated that the plantation boundary agreement with the village was $5 \mathrm{~km}$ but reduced to $1 \mathrm{~km}$. This is because the boundaries between villages are uncertain and have not been determined.

- The extent of PBS threatens the extinction of natural ecosystems in forests and rivers and the loss of cultural sites such as the sacred house and haunted forest. The concept of traditional spatial arrangement is also threatened, specifically the sacred forest areas as forms of traditional spiritual life.

- Village roads are damaged by the moving oil palm trucks, specifically during the rainy season. As a result, road access worsens, forcing villagers to use river transportation. 


\section{CONCLUSION}

The presence of large oil palm plantations brings losses to the indigenous people in Tumbang Marikoi when their living space is taken away. Traditional land is an inseparable part of the life and culture of the Dayak people because it supports survival and is a means to improve social and economic welfare. Therefore, customary lands as part of the rights of indigenous peoples collectively (ulayat) and individually in Central Kalimantan need to be recognized, respected, and valued for their existence.

The implications of forest conversion have resulted in many changes, such as the disturbed river ecosystem due to PETI, river silting due to drilling, the river becoming cloudy, and flooding. As a place to collect vegetables, honey, rattan, and herbal medicines, the forest is getting further away. Furthermore, it is prohibited to clear forests because farming activities by burning are prohibited. The forest is also a magical religious place for ancestors, meaning that this wealth is not proportional to the welfare of the indigenous Dayak community.

The provincial government established the Central Kalimantan Provincial Regulation 16 (2008) Concerning Dayak Indigenous Institutions in Central Kalimantan and Central Kalimantan Governor Regulation 4 (2012) Concerning traditional spatial and customary rights on land in Central Kalimantan Province. This policy should support the indigenous people to live prosperously and in harmony, with written legal backing or positive law regulating regional spatial planning regarding the traditional spatial arrangement. Each customary area has a special right to manage its territory for community welfare.

Competing interests: The authors declare that they have no competing of interests.

Author contributions: Designing the study, data collection, and data analysis: Tari Budayanti Usop, and Sudaryono; Correction of data analysis and correction of writing language: Sudaryono and M. Sani Roychansyah; Conceptualization and correction of data analysis: Tari Budayanti Usop, Sudaryono and M. Sani Roychansyah

Acknowledgments: This writing supported research on Disempowering Traditional Spatial Arrangement of Dayak Community, the case study of Tumbang Marikoi Village, Central Kalimantan, Indonesia. Moreover, the author express gratitude for the opportunity to write in international publication journal lectures at the Department of Architecture and Planning of the Doctoral Program of Universitas Gadjah Mada, Yogyakarta.

\section{REFERENCES}

Amis, J. (2011). Book Review: Amis: Denzin, N. K., \& Lincoln, Y. S. (Eds.). (2008). The landscape of qualitative research. Thousand Oaks, CA: Sage. Organizational Research Methods, 14(1), 239-242. https://doi.org/10.1177/109442810933 2198

BPS Provinsi Kalimantan Tengah. (2020). Kalimantan Tengah Dalam Angka 2020. In B. I. P. dan D. Statistik (Ed.), BPS Provinsi Kalimantan Tengah (pp. 1-885). Palangka Raya. Retrieved from https://kalteng.bps.go.id/publication/download. html?nrbvfeve=YjdhNGIzNTE1MGFkNWZkMTUxMjMwYzQ4\&xzmn=aHROcHM6L y9rYWx0ZW5nLmJwcy5nby5pZC9wdWJsaWNhdGlvbi8yMDIwLzA0LzI3L2I3YTRi MzUxNTBhZDVmZDE1MTIzMGM00C9wcm92aW5zaS1rYWxpbWFudGFuLXRlbm dhaC1kYWxhbS1hbmdrYSOyMDIw

George Bealer. (1999). A Theory Of Thea Priori. Angewandte Chemie International Edition, 6(11), 951-952, 5-24. https://doi.org/10.1111/0029-4624.33.s13.2 
Harrison, M. E., Ottay, J. B., D’Arcy, L., Cheyne, S. M., Anggodo, Belcher, C., ... van Veen, F. J. F. (2019). Tropical forest and peatland conservation in Indonesia: Challenges and directions. People and Nature, (February), 1-25. https://doi.org/10.1002/pan3.10060

Kabupaten Gunung Mas, Provinsi Kalimantan Tengah. (2016). Peta Tumbang Marikoi.

Kabupaten Gunung Mas, Provinsi Kalimantan Tengah. (2018). Peta Sebaran IUPHHK Hutan dan IUPHHK Hutan Tanaman. Kabupaten Gunung Mas.

Mahar, Edi Taufan D. (2020). Jurnal Borneo Institute, Media Informasi, Komunikasi dan Kritik Kebudayaan Dayak Kalimantan Tengah, 1, 7-8.

Pemerintah Republik Indonesia. (2012). Keputusan Menteri Kehutanan Republik Indonesia No. SK.529/Menhut-II/2012 tentang Perubahan Atas Keputusan Menteri Pertanian No. 759/Kpts/UM/10/1982 tentang Penunjukkan Areal Hutan di Wilayah Provinsi Daerah Tingkat I Kalimantan Tengah seluas $\pm 15.300 .000 \mathrm{H}$.

Peraturan Pemerintah Republik Indonesia Nomor 6 Tahun 2007 Tentang Tata Hutan Dan Penyusunan Rencana Pengelolaan Hutan, Serta Pemanfaatan Hutan (2007). https://doi.org/10.7591/cornell/9780801452505.003.0003

Peraturan Pemerintah Republik Indonesia Nomor 82 Tahun 2001, Tentang Pengelolaan Kualitas Air dan Pencemaran Air. (2001) (pp. 1-32).

Peraturan Presiden RI. Undang-Undang Republik Indonesia Nomor 41 Tahun 1999 Tentang Kehutanan, Presiden Republik Indonesia (1999).

Peraturan Presiden RI. (2007). Undang-Undang Republik Indonesia Nomor 26 Tahun 2007 Tentang Penataan Ruang.

Peraturan Gubernur Kalimantan Tengah Nomor 4 Tahun 2012 Tentang Perubahan Peraturan Gubernur Kalimantan Tengah Nomor 13 Tahun 2009 Tentang Tanah Adat dan Hak-Hak Adat di Atas Tanah.

Peraturan Gubernur Kalimantan Tengah Nomor 16 Tahun 2008 tentang Kelembagaan Adat Dayak di Kalimantan Tengah. Retrieved from https://jdih.kalteng.go.id/ uploads/prokum-2013081911342758.pdf

Riwut, T., \& Mantikei, S. (2012). Maneser Panatau Tatu Hiang, Menyelami Kekayaan Leluhur. (N. Riwut, Ed.). Pusaka Lima.

Sangalang, I. (2013). Keterikatan Pada Tempat Hunian di Tepi Sungai: Referensi Suku Dayak Ngaju, Palangkaraya. Institut Teknologi Sepuluh Nopember. Retrieved from http://repository.usu.ac.id/bitstream/123456789/23790/4/Chapter I.pdf

Sudaryono. (2012). Fenomenologi Sebagai Epistemologi Baru Dalam Perencanaan Kota Dan Permukiman. Pidato Pengukuhan Jabatan Guru Besar Pada Fakultas Teknik Universitas Gadjah Mada, 1-25.

Turinawe, E. B., Rwemisisi, J. T., Musinguzi, L. K., de Groot, M., Muhangi, D., de Vries, D. H., Pool, R. (2015). Selection and performance of village health teams (VHTs) in Uganda: Lessons from the natural helper model of health promotion. Human Resources for Health, 13(1). https://doi.org/10.1186/s12960-015-0074-7

Usop, KMA. (1996). Pakat Dayak, Sejarah Integritas dan Jati Diri Masyarakat Dayak Daerah Kalimantan Tengah. Yayasan Pendidikan dan Kebudayaan Batang Garing.

Usop, L. S. (2020). Peran Kearifan Lokal Masyarakat Dayak Ngaju untuk Melestarikan Pahewan (Hutan suci) di Kalimantan Tengah. Universitas Palangka Raya, 1(1), 89-95.

Usop, Tari Budayanti, D. A. I. (2020). Pengaruh Kegiatan Industri Terhadap Spasial dan Sosial Ekonomi di Desa Tumbang Marikoi, Kecamatan Damang Batu, Kabupaten Gunung Mas. Space, 7, 95-114. 
Usop, T. B., Subroto, T. Y. W., Sudaryono, S., \& Roychansyah, M. S. (2021). A Bornean Longhouse in Kahayan and Kapuas River Basin: The Process of Metamorphosis Architecture. International Journal of Disabilities and Social Inclusion, 1(1), 2740.

Vagle, M. D., Clements, C. H., \& Coffee, A. C. (2017). Analytic Productions in PostIntentional Phenomenological Research. Cultural Studies - Critical Methodologies, 17(6), 427-441. https://doi.org/10.1177/1532708616643983 